\title{
Cytotoxic effects of infusions (tea) of Solidago microglossa DC. (Asteraceae) on the cell cycle of Allium cepa
}

\author{
Margarete Dulce Bagatini, ${ }^{1}$ Juliana Maria Fachinetto, ${ }^{2}$ Antonio Carlos Ferreira da Silva, ${ }^{2}$ \\ Solange Bosio Tedesco ${ }^{* 2}$
}

${ }^{1}$ Departamento de Química, Laboratório de Enzimologia, Universidade Federal de Santa Maria, Av. Roraima, 1000, Prédio18, Sala 2208, 971105-900 Santa Maria-RS, Brasil

${ }^{2}$ Departamento de Biologia, Laboratório de Citogenética Vegetal e Genotoxicidade, Universidade Federal de Santa Maria, Av. Roraima, 1000, Prédio16, Sala 3118, 97105-900 Santa Maria-RS, Brasil

\begin{abstract}
RESUMO: "Efeitos citotóxicos das infusões (chá) de Solidago microglossa DC. (Asteraceae) no ciclo celular de Allium cepa". A espécie medicinal Solidago micrglossa DC., a qual é nativa da América do Sul, é usada como infusão (chá) para desordens estomacais na medicina popular. O objetivo desse estudo foi avaliar o potencial efeito citotóxico dessas infusões no ciclo celular de Allium cepa. Folhas in natura de três populações dessa espécie foram utilizadas no preparo das infusões em duas concentrações: $1,75 \mathrm{mg} / \mathrm{mL}$ e $14 \mathrm{mg} / \mathrm{mL}$. Células de raízes de cebola (Allium cepa) foram usadas como sistema teste nos ensaios in vivo. As lâminas foram feitas através da técnica de esmagamento. As células foram analisadas em todos os ciclos celulares de $A$. cepa, totalizando 6000 células para cada grupo de bulbos. O índice mitótico (IM) foi calculado e a análise estatística foi realizada através do teste Qui-quadrado $\left(\chi^{2}=0,05\right)$. Os resultados mostraram que as infusões de $S$. microglossa na maior concentração $(14 \mathrm{mg} / \mathrm{mL})$ causou uma redução no IM comparado com os controles nas populações estudadas. Nas concentrações comumente usadas pelas pessoas houve um aumento significativo do IM em relação ao controle nas populações 1 e 3 e foi reduzido na população 2. Em conclusão, infusões de S. microglossa apresentam efeito antiproliferativo na maior concentração testada.
\end{abstract}

Unitermos: Sistema teste vegetal, planta medicinal, citotóxico, Solidago microglossa, Asteraceae.

\begin{abstract}
The medicinal specie Solidago microglossa DC., which is native from South America, is used as infusion (tea) for stomach disorders in popular medicine. This study aimed to evaluate the potential cytotoxic effect of these infusions on the cell cycle of Allium cepa. In natura leaves of three populations of this species were used in preparing infusions at two concentrations: $1.75 \mathrm{mg} / \mathrm{mL}$ and $14 \mathrm{mg} / \mathrm{mL}$. Onion (Allium cepa) root-tip cells were used as test system in in vivo assays. Slides were done through smashing technique. Cells were analyzed in all cell cycles of $A$. cepa, totalizing 6000 cells for each group of bulbs. The mitotic index (MI) was calculated, and the statistical analysis was carried out through the Chi-square test $\left(\chi^{2}=0.05\right)$. The results show that the infusions of $S$. microglossa at a highest concentration $(14 \mathrm{mg} / \mathrm{mL})$ caused a significant reduction in the MI compared with control in the studied populations. In concentrations commonly used by people there was a significant increase of MI in relation to controlled populations 1 and 3 and a decrease in population 2. In conclusion, infusions of $S$. microglossa presented antiproliferative effect at a highest concentration.
\end{abstract}

Keywords: Test system vegetal, medicinal plant, cytotoxic, Solidago microglossa, Asteraceae.

\section{INTRODUCTION}

In Brazil, the use of crude plant extracts, infusions or plasters is a widespread practice in the treatment of pathologies (Bighetti et al., 2005; Marliére et al., 2008; Veiga-Junior, 2008). However, their inappropriate and not controlled use may cause more damages than benefits to human health (Amorim et al., 2007; Lanini et al., 2009). So, having a deep knowledge of these plants is important even from cell levels to the effects upon live organisms.

According to the World Health Organization (WHO), about $65-80 \%$ of the developing countries depend on plants to heal from diseases, due to poverty and lack of modern medicine access. However, few plants have been studied scientifically in order to evaluate their safe and efficacy (Calixto, 2005; Silveira et al., 2008; Tagliati et al., 2008; Nascimento et al., 2009).

Solidago microglossa (Asteraceae) is among 
the species of medicinal plants used as tea in alternative medicine in South America. In Brazil, it is known by popular names such as "arnica-silvestre", "erva-lanceta", "arnica" and "brazilian-arnica". S. microglossa leaves are used for stomach disorders, adstringent, cicatrizing, acnes and bruises (Lorenzi, 2000). The phytochemical study of this species demonstrated the presence of quercitrin, a glicosidic flavonoid, and also tanines, saponines, resins and essential oils in the tips, as well as inulin and rutine diterpines, quinine acid, rhamnoides and caffeic acid, chlorogenic and hydrocynamic and their derivates in the roots (Torres et al., 1989). Some studies have reported the cicatrizing and antimicrobial activity of the S. microglossa (Neto et al., 2004; Morel et al., 2006). However, there are no data in the literature, at least of our knowledge, with regard to the cytotoxicity of this medicinal plant popularly used.

Studies concerning the toxicity and mutagenicity of medicinal plants are needed to verify the efficacy and safety of their use in the treatment of some diseases (Macêdo et al., 2008; Ferreira et al., 2009). In this context, meristematic cells of Allium cepa are often used as a vegetal test system to indicate the genotoxic potential of the medicinal plant extracts. Moreover, this system can be useful to evaluate the mutagenic activity of specific drugs due to its sensitivity and its relationship with the mammal test system (Grant, 1978; Fiskesjo, 1993; Grisolia \& Takahashi, 1990; Grover et al., 1990; Rank \& Nilsen, 1997; Chauhan et al., 1999; Bagatini et al., 2007).

Thus, the present study aimed to evaluate the cytotoxic potential of infusion (tea) of $S$. microglossa on the A. cepa cell cycle.

\section{MATERIAL AND METHODS}

\section{Plant collection}

Leaves of S. microglossa were collected from three sites in Rio Grande do Sul State, Brazil. The sites were: Boca do Monte/Santa Maria (population 1), São Sepé Road - BR 392 (population 2), São Pedro (population 3 ). From each collected population, there was a voucher sample at the university herbarium, under register number 9928, 9686 and 9689, respectively. The plants were identified by Professor Dr. do Canto-Dorow.

\section{Infusions preparation}

In natura leaves of S. microglossa were put in boiling water, remaining in infusion for $10 \mathrm{~min}$. The aqueous extracts were filtered and cooled at room temperature. The infusions were prepared at two concentrations, each one corresponding to one treatment: $1.75 \mathrm{mg} / \mathrm{mL}$ (treatment 1) and $14 \mathrm{mg} / \mathrm{mL}$ (treatment 2 ). The concentration popularly used to prepare the medicinal tea is $1.75 \mathrm{mg} / \mathrm{mL}$.

In this study, three groups of six onion bulbs were used for each population of S. microglossa, each group represents one of the treatments. All bulbs were put in distilled water to take root, after that they were transferred to infusions that were at room temperature, remaining for $24 \mathrm{~h}$ (control bulbs remained in distilled water). After, root-tips from 5 to $10 \mathrm{~mm}$ were collected and fixed in ethanol:acetic acid $(3: 1)$ for $24 \mathrm{~h}$. Next, they were withdrawn from the fixer and were kept in ethanol $70 \%$ and maintained in the cooler to their use (modified from Camparoto et al., 2002).

\section{The effect of infusion on the cell division of the anion root-tips}

An average of five slides were made for each bulb of each treatment and control of the three population studied. In preparing the slides, root-tips were hydrolyzed in HCI $1 \mathrm{M}$ for $5 \mathrm{~min}$. The meristematic region of the roottips was fragmented and stained with acetic orcein $2 \%$ by using squashing technique (Guerra, 1999).

Analyses of cells from each bulb/population were carried out. The total number of analyzed cells per bulb group was 6000 . Slides were evaluated by observing cells in interphase, prophase, metaphase, anaphase and telophase with the use of an optical microscope with a 40x objective. The average number of cells in each phase of the division cycle of $A$. cepa and the mitotic index (MI) was calculated.

\section{Statistical analysis}

Statistical analysis of the data was performed through the use of $\chi^{2}$ test at probability level of $<0.05$ BioEstat 4.0 (Ayres et al., 2005) has found the results as statistically significant.

\section{RESULTS AND DISCUSSION}

The total number of analyzed cells, the number of cells in division during the cell cycle of A. cepa and the mitotic index (MI) values are displayed in Table 1. The results presented in Table 1 show that the infusions of $S$. microglossa at a highest concentration $(14 \mathrm{mg} / \mathrm{mL})$ caused a significant reduction in the MI compared with control in the studied populations (population $1\left(\chi^{2}=17.96\right)$, population $2\left(\chi^{2}=374.6\right)$ and population $\left.3\left(\chi^{2}=7.36\right)\right)$.

In population 1 and 3 , the values of MI increased in the concentrations of $1.75 \mathrm{mg} / \mathrm{mL}\left(\chi^{2}=12.58\right.$ and $\chi^{2}=$ 7.66 ), compared with control group. In population 2 , it was observed a significant reduction in the MI as the concentrations of infusion of $S$. microglossa were increased $\left(\chi^{2}=32.63\right)$.

Taken together, these results indicate that infusions of S. microglossa present cytotoxic but not mutagenic effect, based in an in vivo vegetal test system. The cytotoxic and antiproliferative effects of $S$. microglossa were observed 
through the diminishing of the mitotic index that occurred in all populations tested, when the highest concentration of $S$. microglossa infusion was used. According with our data, it has been reported that the seasonal variation, the climate, soil and collection period may be responsible for the differences in the chemical composition of plants of this species (Dias, 2001).

Besides the great number of cells analyzed, it was not observed any kind of chromosomal alteration in the cells from onion root-tips neither in control nor in treatment with infusion of $S$. microglossa, which is visible with the use of an optical microscope. These results suggest the absence of mutagenic effects of S. microglossa infusion in the concentrations used in this study.

It is worth highlighting that the test system of $A$. cepa is well known and recognized for cytotoxic studies. This system permits the direct contact of root-tips with the tested substance, becoming possible to run the evaluation of different concentrations in different periods of treatment. The studies carried out with the $A$. cepa test system are considered satisfactory as indicators of the genotoxic potential of the plant extract. In addition, this system has been used as an indicator of the chromosomal alterations in order to warn human people about some product consumption (Vicentini et al., 2001). Being particularly considered important, several researchers have performed the in vitro animal test together with the test system of A. cepa, obtaining similar results (Chauhan et al., 1999; Vicentini et al., 2001; Teixeira et al., 2003), providing valuable information for the human health.

Solidago microglossa is a vegetal species which contains tanines and flavonoids among other substances in its chemical composition. Tanines acts in the protein precipitation and enzymatic inhibition. The enzymatic activity assigned to these compounds can be responsible for the inhibition of cell division in meristematic cells of A. cepa (Teixeira et al., 2003). This species also contains flavonoids, which have been reported to possess cytotoxic activities (Ya-Qin et al., 2001). The flavonoids from Humulus lupulus L. and Lonchocarpus spp. presented cytotoxic and antiproliferative activity in cell cycle on cancer prostate cells (Delmulle et al., 2006; Borges-Argáez et al., 2007). However, the infusions from Maytenus ilicifolia and Bauhinia candicans, despite contain tanines and flavonoids, did not present inhibition of cell division. In addition, according to Bu-Abbas et al. (1996), the high concentration of these substances could be responsible for the antimutagenic activity and probably anticancerigen of the green tea.

Knoll et al. (2006) studied the genotoxic potential of different populations of Pterocaulon polystachyum, displaying their antiproliferative capacity, by using the A. cepa test. During the test, the inhibition of $A$. cepa cell division increased in a concentration dependent manner. Similar results were obtained by Fachinetto et al. (2007) using the $A$. cepa test system to analyze infusions of Achyrocline satureidoides. Moreover, it was observed an increase in the antiproliferative action of Achyrocline satureidoides infusions depending on the plant storage time.

The results of this study with $S$. microglossa infusions at several concentrations and in different populations in the system test $A$. серa show the existence of antiproliferative and cytotoxic activities of this species, suggesting a possible therapeutic potential for the inhibition of the cell cycle in eukaryotic organisms. Further studies should be carried out to establish the main anti-genotoxic components of the $S$. microglossa.

Table 1. Mitotic Index of cells of root-tips of A. cepa treated with extracts of S. microglossa.

\begin{tabular}{cccccc}
\hline Population & Treatments & Total cell number & Cells in interphase & Cells in division & Mitotic index (MI)\% \\
\hline 1 & Control & 6000 & 5696 & 304 & $5.06 \mathrm{a}$ \\
& 1 & 6000 & 5605 & 395 & $6.58 \mathrm{~b}$ \\
2 & 2 & 6000 & 5790 & 210 & $3.50 \mathrm{c}$ \\
& Control & 6000 & 5207 & 793 & $13.22 \mathrm{a}$ \\
& 1 & 6000 & 5407 & 593 & $9.88 \mathrm{~b}$ \\
3 & 2 & 6000 & 5793 & 207 & $3.45 \mathrm{c}$ \\
& Control & 6000 & 5600 & 400 & $6.66 \mathrm{a}$ \\
& 1 & 6000 & 5521 & 479 & $7.98 \mathrm{~b}$ \\
& 2 & 6000 & 5671 & 329 & $5.48 \mathrm{c}$ \\
\hline
\end{tabular}

Means followed by the different letters were different significantly at level $p<0.05$, at $\chi^{2}$ test. Time of treatment: Control $=0 \mathrm{~h}$ ( $\mathrm{t}$ zero), distilled water. Treatments: $24 \mathrm{~h}$ Concentration of infusions: Treatment $1(1.75 \mathrm{mg} / \mathrm{mL})$, Treatment $2(14 \mathrm{mg} / \mathrm{mL})$ of populations 1,2 and 3 of $S$. microglossa. 


\section{ACKNOWLEDGEMENT}

The authors are thankful to Professor Dr. Thais Sctotti do Canto-Dorow for the botanic identification of the species used in the research.

\section{REFERENCES}

Amorim MFD, Diniz MFFM, Araújo MST, Pita JCLR, Dantas JG, Ramalho JA, Xavier AL, Palomaro TV, Júnior NLB 2007. The controvertible role of kava (Piper methysticum G. Foster) an anxiolytic herb, on toxic hepatitis. Rev Bras Farmacogn 17: 448-454.

Ayres M, Ayres JrM, Ayres DL, Santos AS 2005. Bioestat 4.0 In: Aplicações estatísticas nas áreas das ciências biomédicas. Belém, pp 324.

Bagatini MD, Silva ACF, Tedesco SB 2007. Uso do sistema teste de Allium cepa como bioindicador de genotoxicidade de infusões de plantas medicinais. Rev Bras Farmacogn 17 . 444-447.

Bighetti AE, Antônio MA, Kohn LK, Rehder VLG, Foglio MA, Possenti A, Carvalho JE 2005. Antiulcerogenic activity of a crude hydroalcoholic extract and coumarin isolated from Mikania laevigata Schultz Bip. Phytomedicine 12 . 72-77.

Borges-Argáez R, Balnbury L, Flowers A, Giménez-Turba A, Ruiz G, Waterman PG, Penã-Rodríguez LM 2007. Cytotoxic and antiprotozoal activity of flavonoids from Lonchocarpus spp. Phytomedicine 14: 530-533.

Bu-Abbas A, Nunez X, Clifford MN, Walker R, Ioannides C 1996. A comparison of the antimutagenic potential of green, black and decaffeinated teas: contribuition of flavanols to the antimutagenic effect. Mutagenesis 11: 597 603.

Calixto JB 2005. Twenty-five years of research on medicinal plants in Latin America. A personal view. J Ethnopharmacol 100: 131-134.

Camparoto ML, Teixeira RO, Mantovani MS, Vicentini VEP 2002. Effects of Maytenus ilicifolia Mart and Bauhinia candicans Benth infusions on onion root-tip and rat bone-marrow cells. Genet Mol Biol 25: 85-89.

Chauhan LKS, Saxena PN, Gupta SK 1999. Cytogenetic effects of cypermethrin and fenvalerate on the root meristem cells of Allium cepa. Environ Exp Bot 42: 181-189.

Delmulle L, Bellahcène A, Dhooge W, Comhaire F, Roelens F, Huvaere K, Heyerick A, Castronovo V, De Keukeleire D 2006. Anti-proliferative properties of prenylated flavonoids from hops (Humulus lupulus L.) in human prostate cancer cell lines. Phytomedicine 13: 732-734.

Dias GCD 2001. Estudo Fitoquímico da espécie vegetal Solidago microglossa DC. Dissertação de Mestrado em Química. Universidade Federal de Santa Maria, Santa Maria, RS.

Fachinetto JM, Bagatini MD, Durigon J, Silva ACF, Tedesco SB 2007. Anti-proliferative effect of infusions of Achyrocline satureioides on the Allium cepa cell cycle. Rev Bras Farmacogn 17: 49-54.
Ferreira FG, Regasini LO, Oliveira AM, Campos JADB, Silva DHS, Cavalheiro AJ, Santos RA, Bassi CL, Bolzani VS, Soares CP 2009. Avaliação de mutagenicidade e antimutagenicidade de diferentes frações de Pterogyne nitens (Leguminosae), utilizando ensaio de micronúcleo em Tradescantia pallida. Rev Bras Farmacogn 19: 6167.

Fiskesjo G 1993. The Allium test. In: Wastewater Monitoring. Environ Toxicol Water Qual 8: 291-298.

Grant WF 1978. Chromosome aberrations in plants as a monitoring system. Environ Health Perspect 27: 37-43.

Grisolia CK, Takahashi CS 1990. Evaluation of mutagenic effect of the antihypertensive drug methyldopa (Aldomet) on mammalian systems in vivo and in vitro and on Allium cepa. Mutat Res 259: 127-132.

Grover IS, Dhingra AK, Adhikari N, Ladhar SS 1990. Genotoxicity of pesticides and systems. Progr Clin Biol Res 340 . 91-106.

Guerra M 1999. Haematoxylin - a simple multiple use dye for chromosome analysis. Genet Mol Biol 22: 77-80.

Knoll MF, Silva ACF, Canto-Dorow TS, Tedesco SB 2006. Effects of Pterocaulon polystachyum DC. (Asteraceae) on onion (Allium cepa) root-tip cells. Genet Mol Biol 29: 539-542.

Lanini J, Duarte-Almeida JM, Nappo S, Carlini EA 2009. "O que vêm da terra não faz mal" - relatos de problemas relacionados ao uso de plantas medicinais por raizeiros de Diadema/SP. Rev Bras Farmacogn 19: 121-129.

Lorenzi H 2000. Plantas medicinais no Brasil: nativas e exóticas cultivadas. Instituto Plantarum, Nova Odessa, SP.

Macêdo MFS, Sisenando HAAACN, Queiroz JDF, Argolo ACC, Saturnino ACRD, Coelho LCBB, Batistuzzo-deMedeiros SR 2008. Determining the genotoxicity of an aqueous infusion of Bauhinia monandra leaves. Rev Bras Farmacogn 18: 509-516.

Marliére LDP, Ribeiro AQ, Brandão MGL, Klein CH, Acurcio FA 2008. Utilização de fitoterápicos por idosos: resultados de um inquérito domiciliar em Belo Horizonte (MG), Brasil. Rev Bras Farmacogn 18 (Supl.): 754-760.

Morel AF, Dias GO, Porto C, Simionatto E, Stuker CZ, Dalcol II 2006. Antimicrobial activity of extractives of Solidago microglossa. Fitoterapia 77: 453-455.

Nascimento DF, Santana APM, Leite IO, Viana FAC, Leite ALAS, Moraes RA, Jamacaru FVF, Bezerra FAF, Moraes MO, Moraes MEA 2009. Estudo de toxicologia clínica de um fitoterápico contendo Passiflora incarnata L., Crataegus oxyacantha L., Salix alba L. em voluntários saudáveis. Rev Bras Farmacogn 19: 261-268.

Neto MAF, Fagundes DJ, Beletti ME, Novo NF, Juliano Y, Penha-Silva N 2004. Systemic use of Solidago microglossa DC in the cicatrization of open cutaneous wounds in rats. Braz J Morphol Sci 21: 204-210.

Rank J, Nielsen MH 1997. Anaphase-telophase root tip chromosome aberration assay on methyl-nitro urea, maleic hydrazide, sodium azide and ehtylmethane sulphonate. Mutat Res 390: 121-127. 
Silveira PF, Bandeira MAM, Arrais PSD 2008. Farmacovigilância e reações adversas às plantas medicinais e fitoterápicos: uma realidade. Rev Bras Farmacogn 18: 618-626.

Tagliati CA, Silva RP, Féres CAO, Jorge RM, Rocha OA, Braga FC 2008. Acute and chronic toxicological studies of the Brazilian phytopharmaceutical product Ierobina ${ }^{\circledR}$. Rev Bras Farmacogn 18 (Supl.): 676-682.

Teixeira RO, Camparoto ML, Mantovani MS, Vicentini VEP 2003. Assessment of two medicinal plants, Psidium guajava L. and Achillea millefolium L. in in vivo assays. Genet Mol Biol 26: 551-555.

Torres LMB, Akisue MK, Roque NF 1989. Diterpenes from roots of Solidago microglossa. Rev Latinoamer Quim 20: 9497.

Veiga-Junior VF 2008. Estudo do consumo de plantas medicinais na Região Centro-Norte do Estado do Rio de Janeiro: aceitação pelos profissionais de saúde e modo de uso pela população. Rev Bras Farmacogn 18: 308-313.

Vicentini VEP, Camparoto ML, Teixeira RO, Mantovani MS 2001. Averrhoa carambola L., Syzygium cumini (L.) Skeels and Cissus sicyoides L.: medicinal herbal tea effects on vegetal and test systems. Acta Scientiarum 23: 593-598.

Ya-Qin S, Toshio F, Hiroshi S, Wen-Jin C, Pei-Quan Y, FengPeng W, Taro N 2001. Cytotoxic flavonoids with isoprenoids groups from Morus mongolica. J Nat Prod 64: 181-188. 